\title{
A hedonic price analysis of the value of industrial sites
}

Jasper Beekmans, Institute for Management Research, Radboud University Nijmegen, The Netherlands ${ }^{1}$

Pascal Beckers, PBL Netherlands Environmental Assessment Agency, The Hague, The Netherlands

\begin{abstract}
Hedonic price modelling is a widely used technique to explain the value of different types of individual property. Following the notion that areas within the city can suffer from devaluation the question arises what factors influence the value of urban areas. In this paper we use hedonic price analysis to answer this question for a specific type of urban area, the industrial site. We use the average property value per hectare as a representation of the value of an industrial site. Although there are many studies that try to explain the value of individual property, the value of industrial sites as urban areas remains under researched. A distinction is made between three types of explanatory variables: physical characteristics of the industrial site, regional economic characteristics and general economic trends. Our results show that 'mixed-use' sites -a third of all industrial sites in the Netherlands - show the lowest average property values. Specialisation in terms of the composition of firms located on an industrial site appears to have a positive influence on the average property value with specialised types of industrial sites, such as 'transport' and 'consumer services', showing significantly higher average property

values. Furthermore, visibility from motorway and the region in which the industrial site is located (the economic core region Randstad showing the highest average values) also have a significant influence on the value of an industrial site. Although the overall explanatory value of our model appears to be modest compared to existing hedonic pricing studies of individual property, results show that most explanatory variables in our model have the expected coefficients and signs, indicating that this method can be applied in a meaningful way to gain insight into the valuation of urban areas.
\end{abstract}

Keywords: industrial sites, neighbourhood decline, urban decline, hedonic price analysis

\section{Acknowledgements}

Our own calculations on property values are based on taxation data (WOZ) by CBS Netherlands Statistics (CBS), provided by Dutch municipalities. These data were linked to individual industrial sites using the national employment database (LISA). This paper is part of an ongoing research programme and received financial assistance from the Netherlands Institute for Cities and Innovation Studies (NICIS). We are grateful for comments by Friso de Vor, Edwin Buitelaar and Jan Schuur on earlier versions of this paper.

\footnotetext{
${ }^{1}$ E-mail: j.beekmans@fm.ru.nl
} 


\section{Introduction}

Hedonic price modelling is widely used as a technique for the assessment of property value, estimating demand for specific attributes of housing and neighbourhoods and analysing price indexes for different types of property (Páez, Long and Farber, 2007). The aim of this paper is twofold. First, following Bryson's (1997) notion that areas within the city can devaluate, to gain insight into the factors that can help explain the valuation of urban areas. We therefore analyse which characteristics of urban areas influence the value of that urban area. Such an analysis is useful since it can provide insight into what Bryson calls 'locational obsolescence' (Bryson, 1997). Locational obsolescence can be defined as a process that leads to a gradual undermining of the economic potential of a (part of a) city, for example due to a change in function of an area or declining accessibility. According to Bryson's theoretical study, locational obsolescence leads to a devaluation of an area within the city. An actual empirical analysis of the factors that influence the valuation of an urban area can be a useful tool for policy makers to monitor the performance of an urban area in terms of decline. Furthermore, this can be helpful in both maintenance of existing urban areas as well as planning of new urban areas. Although there are many studies that try to explain the value of individual property, the value of urban areas remains under researched. Processes such as neighbourhood decline and gentrification take place at this level and are widely believed to influence the value of property throughout urban areas as a whole (see e.g. Walks and Maaranen, 2008; Heidkamp and Lucas, 2006; Wyly and Hammel, 1998). The abundant literature on prices of individual property points the way as to which types of characteristics could be useful to take into account when analysing the value of an urban area (see e.g. Cheshire and Hay, 1998; Dunse and Jones, 1998). These studies generally distinguish between three categories to determine individual property value, namely characteristics of the property itself, social and environmental attributes of neighbourhoods and other location characteristics such as accessibility (Páez et al., 2007). The present study aims to explore the influence of a variety of physical, economical and other characteristics on the value of an urban area. The selection of characteristics is largely based on present studies that use hedonic price modelling.

The second aim of our study is to test whether a method that is inspired by hedonic price modelling can be applied to urban areas instead of individual property. The classic notion behind hedonic theory as defined by Rosen (1974) is that "goods are valued for their utility-bearing attributes of characteristics" (Rosen, 1974, p.1). This implies that all individual characteristics of a good contribute to the price of that good. However, these characteristics cannot be traded individually. Although an urban 
area is not a good that is traded and consequently does not have a price as such, the rationale behind hedonic analysis that the overall price of an object is determined by the implicit price of its characteristics, can be applied to urban areas as well. Since urban areas are not a priced commodity per se, the value is allocated to the area: the value of an urban area is defined as the aggregate value of the property that is located in that area. A similar approach is used by Reed (2012) in his study on factors that influence the housing value of suburbs in Melbourne. Contrary to his study we do not use the median property price within an area, but an average value per hectare (see section 3.2 ) to be able to compare between urban areas of different size.

In this paper a specific type of urban area is researched: the industrial site. In the Netherlands, industrial sites have gotten significant attention lately because of the rapid decline of these parts of the city (van der Krabben and Buitelaar, 2011). It is often a goal of redevelopment policies to increase the value of the properties on industrial sites as a means to stop decline (Ploegmakers and Beckers, 2012). In this regard, it may prove highly useful to gather insight into how various characteristics influence average property values of industrial sites.

\section{Studies of property value and industrial sites}

\subsection{Hedonic price modelling}

Hedonic price modeling can be applied to explain the value of heterogeneous goods (Dunse and Jones 1998). This heterogeneity is reflected in the different characteristics of an office building, house or industrial property. A precondition that has to be met when assessing the implicit price of each characteristic of a property, is that the properties under research are of comparable types. It is thus not useful to compare the implicit price of accessibility for an office building with the implicit price of the same characteristic for housing. While industrial sites are somewhat more heterogeneous than residential or office areas, we argue that they are sufficiently homogeneous to apply hedonic price modeling. This holds, as we make a distinction between different types of industrial sites accommodating property ranging from heavy industrial to offices.

\subsection{Literature review}

This section provides a brief overview of the literature on the valuation of individual property, in order to find possible explanatory variables that can be included in a model that aims at predicting the average value of industrial sites. The underlying assumption is that some of the factors explaining 
differences in individual property prices can also be used to help predict differences in the change of average property value of an urban area. Not all studies that are discussed in this section are aimed at explaining property prices. Some of the research elaborated here concerns studies or policy reports of industrial sites in general. Although valuation is not the main focus of these studies, they still might provide possible explanatory variables.

What characteristics are taken into account when hedonic price studies asses the price of property depends on the type of property that is under research. In general, property specific characteristics are the most important. However, the characteristics that are considered in housing studies are not necessarily relevant in explaining the value of commercial property. Since our study will deal with industrial sites, we will consider authors that have focused on industrial and commercial property in more detail. Property specific characteristics however will not be included in our analysis Hoag (1980), Ambrose (1990), Fehribach, Rutherford and Eakin (1993), Lockwood and Rutherford (1996), Black, Wolverton, Warden and Pittman (1997), Buttimer, Rutherford and Witten (1997), Jackson (2002) and Ryan (2005) have all studied the prices of industrial property, while Gunterman (1995) has studied prices of industrial land. ${ }^{i}$ Physical aspects of the property itself are found to be the most important explanatory variables in the majority of these studies. Not surprisingly, size of the property is found to be an important variable (Ambrose 1990; Fehribach et al. 1993; Lockwood and Rutherford 1996; Buttimer et al. 1997). The same is true for the age of a property, although some studies do not show significant results (cf: Ambrose 1990; Fehribach et al. 1993; Sivitanidou and Sivitanides 1995; Black et al. 1997; Buttimer et al. 1997; Dunse, Jones, Brown and Fraser 2004; Ryan 2005; Dunse and Jones, 2005). A selection of other characteristics of properties that are included in analyses are the number of dock-high doors (Ambrose 1990), the presence of sprinklers (Buttimer et al. 1997), the type of tenant (Sivitanidou en Sivitanides 1995) and the size of the office area within the industrial property (Black et al. 1997).

Location characteristics are a second type of variables that are taken into account in many studies of the price of property. Most of these can be regarded physical aspects of the (direct) environment of the property under research. The direct surroundings are important to owners of property as can be concluded from studies on the location preferences of firms by, for instance, Pen (2002) and STEC Groep (2005). From these studies it can be concluded that firms prefer to be housed in property that is located among property with a similar representativeness. As a result, firms and their housing at a certain industrial site are comparable to a large extent. De Vor and de Groot (2011) assume that because of this the type of industrial site is a proxy for the appearance of an industrial site since 
similar firms will tend to be located together. Sea ports can be considered an exception to this, because of the very distinct character of the firms located there (PBL Netherlands Environmental Assessment Agency (PBL), 2008) We will further elaborate on sea ports in section 3.2.

Accessibility is another characteristic of the environment that, in a variety of forms, has an influence on property values. Accessibility can be defined in a number of ways. Lockwood and Rutherford (1996) and Sivitanidou and Sivitanides (1995) show that the proximity of an airport has a positive effect on the price of industrial property. Accessibility via road is also an important explanatory variable for industrial property value (see e.g. Sivitanidou and Sivitanides, 1995; Dunse et al., 2004). Dunse and Jones (2005) report similar results for rental values of industrial property and the proximity of a motorway junction. Contrary to that, Ryan's (2005) empirical work shows that a location close to a freeway can be a disamenity for industrial property. Accessibility by rail on industrial property prices is considered in many studies, although most analyses show the influence is limited (see e.g. Ambrose, 1990; Lockwood and Rutherford, 1996; Black et al., 1997; Ryan, 2005). A third form of accessibility has to the best of our knowledge not been researched. This concerns water as a means of transport. For industrial sites the presence of water may be of importance since it creates an extra transport opportunity for especially bulky or heavy goods.

In many studies a factor that is commonly used to characterise the location of property is the distance to CBD. The results for this variable differ between studies. Lockwood and Rutherford (1996) and Ryan (2005) do not find a significant relation between distance from CBD and industrial property value. Dunse et al. (2005) however find a significant, although small, declining rental gradient from the $\mathrm{CBD}$ in a mono-centric city. For industrial property a location further away from the CBD can mean better accessibility (for example via road) and as a result is not necessarily a negative location characteristic. We will elaborate more on the location within the city and the consequences for property values below.

Next to (dis)advantages of a location in terms of proximity and accessibility, location is sometimes also interpreted from another perspective. A location comes with aesthetic aspects that can influence the value of a property. Dunse et al. (2004) provide an example of such a perspective. From their study they conclude that more prestigious location with better visibility show higher property values. For industrial sites, this concerns mostly visibility from a motorway (or other main road).

A location within an urban environment can have significant positive effects on rental values. In their study of office rents, PBL (2009a) defined the urban environment based on the presence of amenities such as restaurants, theatres and shops. For the industrial property in our database, 
unfortunately this information was unavailable. Density was therefore chosen as a proxy for urbanisation rate of the surroundings of the site. It is assumed that higher densities in the direct surroundings indicate a more urban environment. Note that this does not necessarily mean that the industrial site is located close to the CBD.

A final physical characteristic that is elaborated here is not drawn from hedonic pricing studies, but from policy reports on Dutch industrial sites. In practice it is observed that industrial sites can cause nuisance in the form of noise, risk, heavy transport and pollution to neighbouring (residential) areas. Because of increasing environmental regulation the presence of housing can become a factor for the industrial site itself since it effects the attractiveness of the location for certain firms (CPB Netherlands Bureau for Economic Policy Analysis (CPB), 2001; Taskforce Herontwikkeling Bedrijventerreinen, 2008). Nuisance is thus a factor that can influence the attractiveness of property located at a certain location and should for that reason be taken into account when assessing the value of industrial sites.

In Hoag's (1980) seminal work, financial and macroeconomic variables account for the largest part of the explanatory power of the model used to explain the value of industrial properties. Within macroeconomic variables Hoag distinguishes between regional and national variables. Other studies have followed this notion and a variety of financial and economic variables are taken into account in almost all hedonic price studies. This wide range includes proxies for economic circumstances such as occupancy rates (Buttimer et al. 1997), manufacturing wage and labour union strength (Black et al. 1997). Lockwoord and Rutherford (1996) have set out to test whether both national and regional economic characteristics influence industrial property value. Their results "do not support the inclusion of national concomitants of value as hypothesized by Hoag" (Lockwood and Rutherford 1996, p. 269). Following this conclusion, in this study the emphasis will be on regional economic characteristics.

Jackson (2002) differentiates between different (sub)counties in his study on industrial property sales in Southern California, indicating that agglomeration effects are expected. Dunse and Jones (2005) find similar differences between regional property markets around Glasgow. Without specifying the exact spatial-economic differences, De Vor and de Groot (2011) use a similar argumentation to predict higher prices of residential property in the Randstad (the economic most important region of the Netherlands) versus a province outside the economic core region: "Since the Randstad is the economic core region of the Netherlands, dwellings located in this region are hypothesized to sell at a higher price than dwellings in North-Brabant" (de Vor and de Groot 2011, p. 615). Their results show that this is indeed the case, providing an argument to include a region variable to control for specific economical characteristics that are present at this level. Although it is beyond the scope of this paper to discuss all 
regional effects in detail, one effect that we will highlight here is scarcity for industrial land. Sivitanidou and Sivitanides have studied the relation between supply and rental levels of industrial rents in Los Angeles and find that supply indeed influences rental levels (Sivitanidou and Sivitanides, 1995). According to Needham (1992), scarcity should be taken into account at a regional level since the market for industrial land usually covers an area that is larger than a municipality. Although it is not researched empirically, a relation is assumed between the abundant provision of new industrial sites and negative effects such as rapid decline of existing sites, high vacancy rates and declining property values. The rationale behind this relation is that higher levels of scarcity for industrial land make it more difficult for firms to move to another site since land is not readily available. Instead, firms decide to invest in their existing premises (see e.g. Louw, Needham, Olden and Pen, 2004). The inclusion of a region variable will control for regional effects such as scarcity and agglomeration effects.

In addition to the influence of the economic characteristics of a region, there is evidence that suggests that the size of the municipality is also a factor that should be taken into account. In the case of industrial property in Dallas and Tarrant county, a positive coefficient for the former is expected, "because Dallas is larger and has larger manufacturing and distribution industries" (Fehribach et al. 1993, p. 369). The size of the municipality an industrial site is situated in should thus be taken into account.

The distinction between regional and national economic factors was already made above. Although we have concentrated on regional economic variables, there is a number of studies in which year dummies are taken into account to control for general economic trends. In her analysis of office and industrial rental values, Ryan (2005) argues that the inclusion of a dummy variable for year of observation adequately captures economic up- and downturns. Glascock, Jahanian and Sirmans (1990) and Wheaton and Torto (1994) use similar interpretations of year dummies and find the expected significant results for these variables. From this, we conclude that average industrial property values will also be affected by economic trends that we will capture in a likewise fashion by including year dummies.

\section{Empirical analysis: value of industrial sites}

\subsection{Introduction}

In section 2, various hedonic pricing studies and studies on industrial sites were discussed. A large variety of characteristics that influence the value of individual property or the functioning of industrial 
sites was presented. In this section, we concentrate on the specification of the model that will be used to explain the value of industrial sites.

We use ordinary least squares (OLS) regression on our panel data of the period 1997-2008 to analyse the relationship between average property values and a number of independent variables that are expected to influence this value. Most studies that use hedonic price modelling aim at explaining prices of property (rental, asking or sales prices are the most commonly used variables). Collection of data on sales and rentals is difficult since the amount of transactions of industrial property is relatively low. Moreover, this data is scattered and not easily accessible. However, appraisal data on property values, used for taxation purposes, are available. Based on these values, the value per industrial site can be calculated.

The first step that was needed to be able to assign a value to individual sites was to define industrial sites. The definition used here is based on the Dutch national database on industrial sites, IBIS. It contains basic information such as surface area, land prices, available land, geographical information on location, etc. for every industrial site in the Netherlands. An industrial site is defined as a site which, according to the land use plan is suitable for the functions of trade and industry and commercial and non-commercial services. This also includes a limited number of (parts of) locations that are zoned and being used for offices (IBIS 2012). Dedicated office locations, typically located in or close to city centres and railway stations, however, are not included in this definition. Due to privacy reasons, industrial sites with less than 5 properties had to be excluded from our analysis.

In section 3.2 the dependent variable as well as the explanatory variables that are based on the literature review above are presented. Table 1 lists all variables as well as the descriptive statistics and an operational definition for each variable. The specification of the model is given in section 3.3. Section 3.4 presents the results of our empirical analysis.

\subsection{Specification of variables}

\section{Dependent variable}

For the construction of the dependent variable data were obtained from CBS Netherlands Statistics (CBS). Appraised values were derived from their database on property taxation for the period 19972008. For every year the total property value for each industrial site was divided by its net surface area in hectares," which rendered the property value per hectare for every year in the period under research. This value is referred to as the average industrial property value. As was mentioned before, many hedonic pricing studies use rental or selling prices as dependent variable. Appraisal values for taxation 
are believed to be similar to such values, as the instruction for valuators states that the appraisal value should represent transaction prices (Waarderingskamer, 2011). ${ }^{\text {iii }}$ It is therefore assumed that appraisal value is a good indicator of the property values that are commonly used in hedonic price studies, i.e. (listed) selling prices and rents. Derbes (2002) actually provides an argument to use appraisal value over transaction prices: “(...) viable, profitable manufacturing plants seldom sell, since owners usually retain them until they become unprofitable. When they do sell, the sale is usually a total enterprise that includes machinery, equipment, patents and other intangibles. The allocation of assets in such cases becomes extremely difficult" (Derbes 2002, p. 40).

\section{Explanatory variables}

In section 2 it was mentioned that in hedonic pricing literature the physical characteristics of individual property normally account for a large part of the explanation of the prices of individual property. Since the level of analysis here is the industrial site, we focus on physical characteristics of the industrial site instead. The relationships between various explanatory variables and the dependent variable will be hypothesised here. All variables have reference categories as listed in table 1.

With a few exceptions all explanatory variables were calculated for every year in the period under research. This is necessary for variables such as nuisance, type of industrial site, density and accessibility since these are subject to change. The variables region, urbanisation rate, and age (defined as the period in which an industrial site was developed, see below) are (much more) static and are assumed not to have changed within the period under research. For the type of industrial site for example, yearly values were calculated by linking the geographical information in IBIS to a database with addresses of individual firms which contains information on the type of economic activity of the company. Based on the types of firms located at an industrial site, a classification of types of industrial sites was made for every year. Similar methods were applied to calculate yearly values for other variables.

Not all variables were available for every year in the period under research. For the variables accessibility, water, centrality and located along motorway data was available for the years 1997, 2002 and 2008. The values for missing years were calculated assuming a moving average when changes had taken place between two years, to allow for yearly analysis with all variables included. 


\section{Physical characteristics of the industrial site}

Physical characteristics of the industrial site that are included in the analysis are 'type of industrial site', 'seaport, 'accessibility', 'nuisance', 'centrality' and 'age'.

Six different types of industrial sites are distinguished: 'industry', 'mixed-use', 'logistics', 'consumer services', 'business and financial services' and 'miscellaneous'. iv Mixed-use industrial sites are the reference category for this variable. We expect that 'business and financial services', 'consumer services' and 'miscellaneous' will have a higher average property value vis-à-vis 'mixed-use' sites as firms that are typically located on these types of industrial sites will have higher demands regarding accessibility, representativeness and other value-adding characteristics. The opposite is expected to be true for owners of property at 'industry' and 'logistics' sites. Therefore, the coefficients for these categories are expected to show a negative sign.

Secondly, a dichotomous variable is added to the model to control for sea ports. The identification of sea ports is based on the same existing database that was mentioned above (additional corrections were carried out by researchers from PBL Netherlands Environmental Assessment Agency to identify sea ports more thoroughly). Sea ports do not belong to one of the categories of types of industrial sites since the firms located at sea ports could be anything ranging from transport to heavy industrial. Sea ports could thus be characterised as either logistics, industry or mixed use. Still, sea ports have certain distinct characteristics (such as a low density) that influence the average property value that can be controlled for via the inclusion of this variable.

The third explanatory variable in our model is 'accessibility'. Three categories are distinguished. Accessibility by road is measured in travelling time in minutes to the nearest motorway exit. ${ }^{v}$ The second category is 'accessibility by public transport'. This category is defined as distance in meters from the nearest bus stop. An increasing distance from a motorway exit or bus stop is expected to have a negative effect on the average industrial property value, which means that a negative sign is expected for both categories of this variable. A third category is presence of water. The amount of open water (measured in 10x10 meter grid cells) within a 500 meter radius of the industrial site is determined using topographical maps. The presence of water is expected to affect average property values positively since it is seen as a proxy for an extra means of transport.

'Located along a motorway' is the next variable included in the model. This dichotomous variable takes value 1 if the industrial site intersects with a motorway. Note that a location along a motorway does not automatically mean that the location is very well accessible; the exit of the motorway does not necessarily have to be nearby. ${ }^{\mathrm{vi}}$ 
The location of property relative to a central place such as a city centre is studied by different authors. For industrial property the relationship is not always straightforward. Although a central location can have advantages such as agglomeration effects, for industrial sites, being located further away from the centre of a municipality might have advantages when it comes to e.g. accessibility. This ambiguity seems less apparent for offices or residential property. Ryan's study seems to confirm this: "In terms of industrial properties [as opposed to offices], the overall results demonstrate that transport access may be weaker than localisation benefits" (Ryan 2005, p. 763). Dunse and Jones (2005) found a negative correlation between industrial rent and distance from nearest large town. Following these conclusion we expect a negative sign for both distance to CBD and centre of municipality.

Topographical maps were also used to determine the age of an industrial site. The present location of every industrial site was researched on historical topographical maps that were updated roughly every decade. Whenever the historical maps showed the present location as developed, this gave us information on the decade in which the industrial site was first developed. ${ }^{\text {vii }}$ The variable 'age' is thus defined as the decade in which the industrial sites were first developed. Six different age categories were used ranging from '1950s and before' to '2000s', with evenly distributed age brackets in between.

The final physical characteristic used is 'nuisance'. Whether an industrial site is hindered by functions surrounding it, is determined by determining the land uses surrounding the industrial site. For every industrial site, the presence of the land uses 'housing' and 'open space' (again in 10x10 meters grid cells) within a 500 meter radius of an industrial site were determined. Higher levels of housing surrounding the industrial site are expected to have a negative relation with average property value. Conversely, a positive sign is expected for the category 'open space'.

\section{Regional economic characteristics}

Regional economic variables included in the model are 'region', 'urbanisation rate' and 'density' As mentioned before, we distinguish between three different regions in the Netherlands based on economic significance: Randstad (the economic heartland of the Netherlands), an intermediary zone, and the periphery (see figure 1). This division is based on quantile scores of number of jobs in municipalities. For an earlier version and more information on the methods see van Oort (2004). Considering the economic difference between these three parts of the Netherlands it is expected that the average industrial property values will be highest in the central region, followed by the intermediary zone and the periphery, respectively. 
Figure 1: distinction between three regions in the Netherlands (source: Lisa, 2007). Visualisation by PBL Netherlands Environmental Assessment Agency. Municipal Boundaries from 2008 were used.

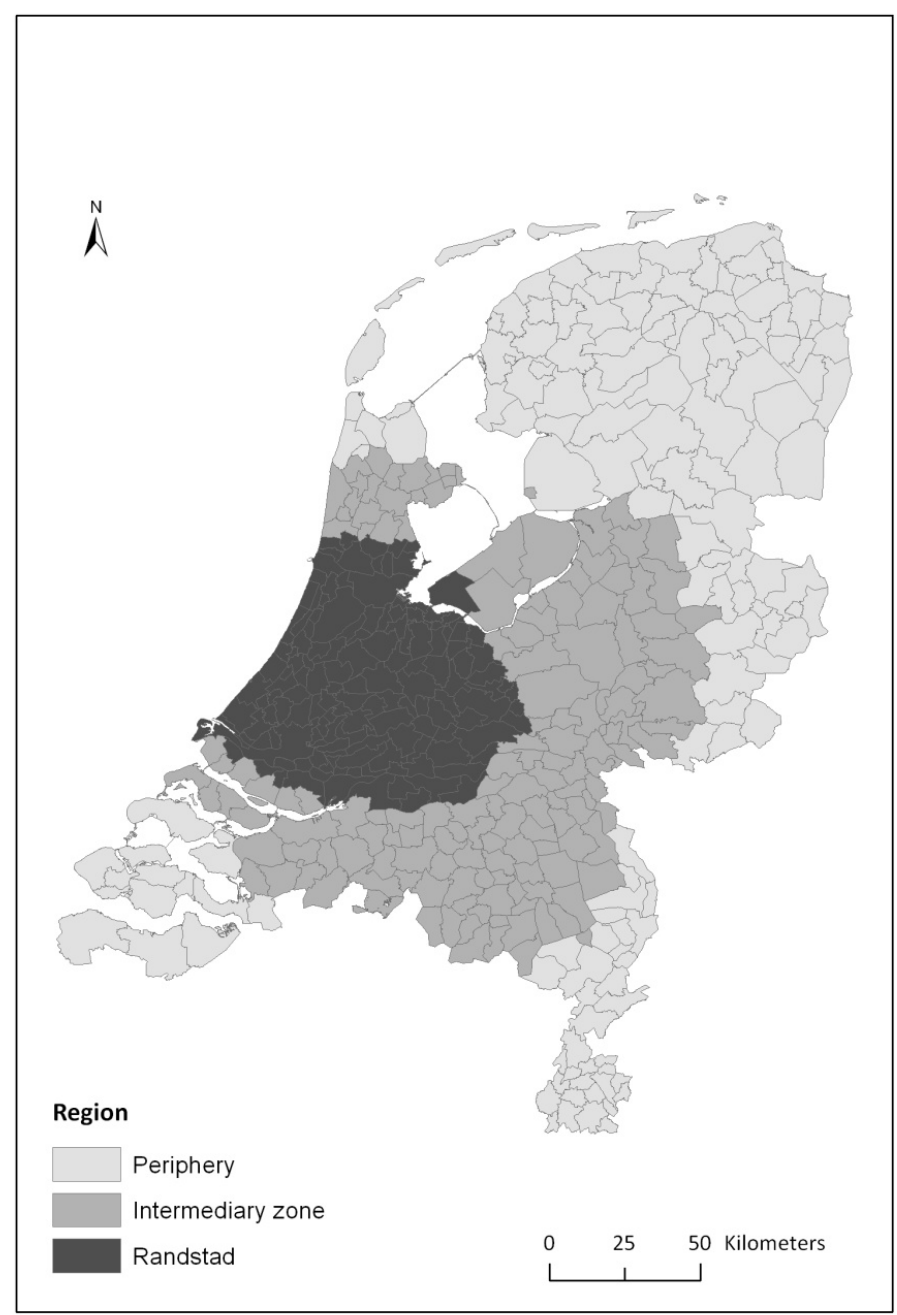

Also, the 'urbanisation rate' is included in the model. Three different categories are distinguished: urban agglomeration, suburban, and other. CBS provides the definitions that were used to characterise the municipalities. CBS has defined 22 urban agglomerations throughout the Netherlands, based on morphological characteristics, population and amount of jobs (for the exact definitions see CBS, 2005). The municipalities that are located just outside the urban agglomeration are labelled as suburban. The remaining municipalities are classified as other municipalities. Average industrial property values are believed to be highest in urban agglomerations, followed by suburban and other municipalities respectively.

The final regional economic variable that is included in the model is 'density'. Again, this variable is defined by CBS and measures the number of addresses within a 1 kilometre radius of the industrial site. 
An average density of addresses was calculated for every industrial site, using the method mentioned before.

\section{Economic trends}

A year dummy was included in the model to control for general economic trends. Economic trends for industrial sites in the Netherlands have been described by Louw et al. (2004). Following their study, we expect average industrial property values to increase annually compared to the reference year 1997. Furthermore, based on data of sales of industrial property provided by STRABO (Vastgoedmonitor 2012) we expect a bust in the coefficients for the years 2003-2006.

\subsection{Model specification}

The above leads to the following functional form of our model (see table 1 for description of variables):

$$
\ln P V_{i t}=\hat{\alpha}+\sum_{a=1}^{N} \hat{\beta}_{a} P C_{i t}+\sum_{b=1}^{N} \hat{\gamma}_{b} R E C_{r t}+E T_{t}
$$

where:

$\ln P V_{i t}$ ? :Natural logarithm of the average industrial property value (in $€$ per hectare) on site (i) in year $(\mathrm{t})$ $\sum_{a=1}^{N} \hat{\beta}_{a} P C_{i t} \quad$ :Physical characteristics of site (i) in year (t) (type of industrial site, sea port, accessibility road, municipality, distance from CBD, age, nuisance housing, nuisance open space);

$\sum_{b=1}^{N} \hat{\gamma_{b}} R E C_{r t} \quad:$ Regional economic characteristics in region $(\mathrm{r})$ in year (t) (region, urbanisation rate, density);

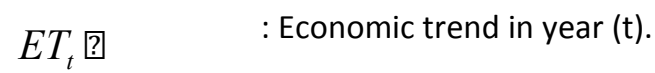

The dependent variable was transformed using a natural logarithm. Although the literature is ambiguous on which method should be applied as this depends on the specific situation (Malpezzi 2003), for this study a semi- logarithmic model was chosen. The main reason for this is that it allows easy interpretation of the coefficients of the explanatory variables. These can be interpreted as the change in value in terms of percentages when the explanatory variable increases with one unit (for more advantages of a semi-logarithmic model see: PBL, 2009a). Multicollinearity is a common problem when applying hedonic price models. To test for this, we follow Belsley, Kuh and Welsch (2004) and calculate 
the variance inflation factors (VIF) of all explanatory variables included in the model. The results of this analysis show that our findings will not suffer from multicollinearity.

Table 1: Descriptive statistics of the variables included in model

\begin{tabular}{llllc}
\hline Variable name & Operational description & $\begin{array}{l}\text { Categories (when } \\
\text { applicable) Reference } \\
\text { categories in bold }\end{array}$ & Mean & SD \\
\hline $\begin{array}{l}\text { Dependent variable } \\
\text { Average property value }\end{array}$ & $\begin{array}{l}\text { Average industrial } \\
\text { property value (in } € \text { per } \\
\text { hectare) on site }\end{array}$ & - & $€ 92,993$ & $€ 179,430$ \\
& & & CBS \& IBIS \\
Explanatory variables & & &
\end{tabular}

\section{Physical characteristics of industrial sites}

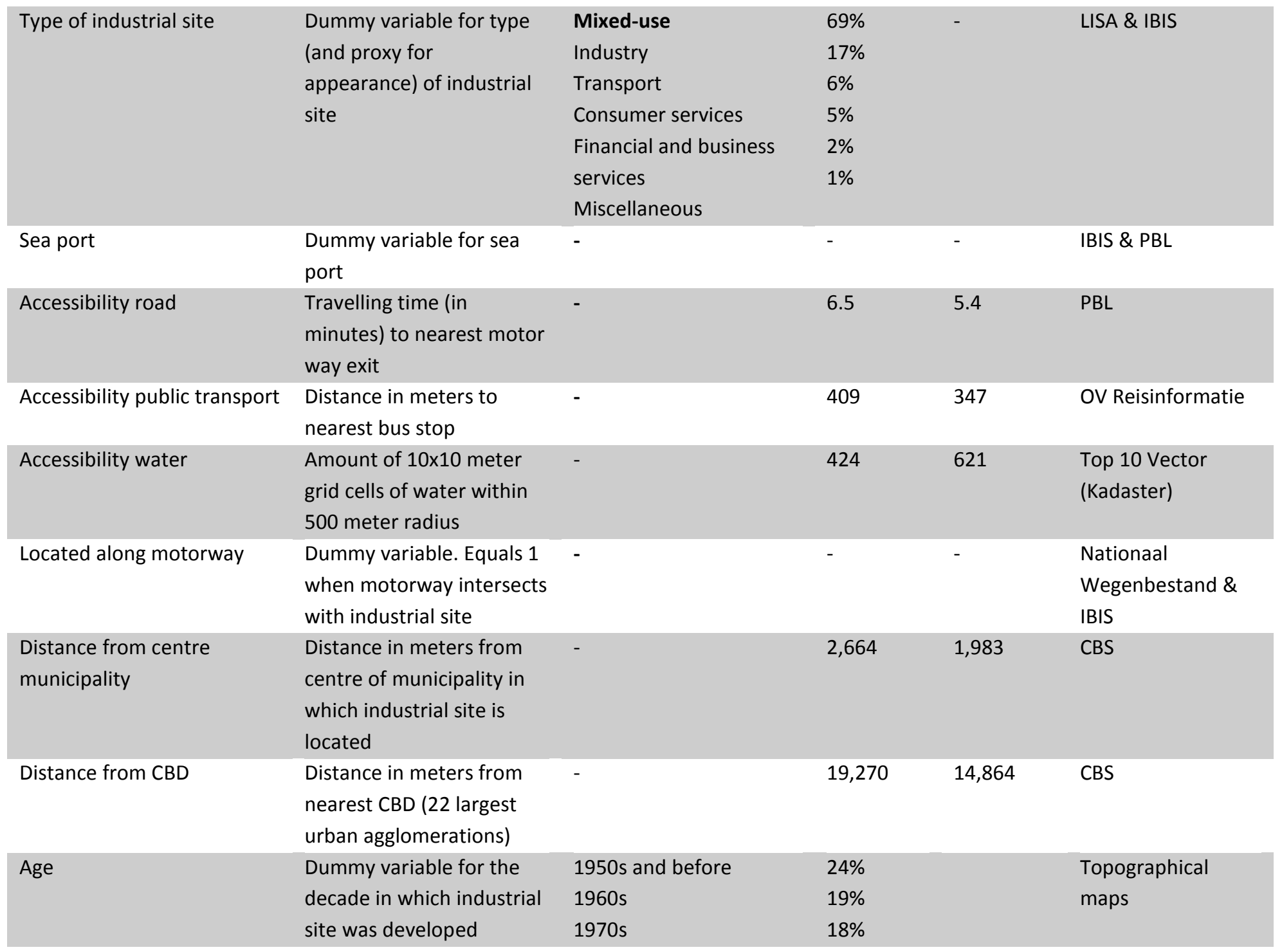




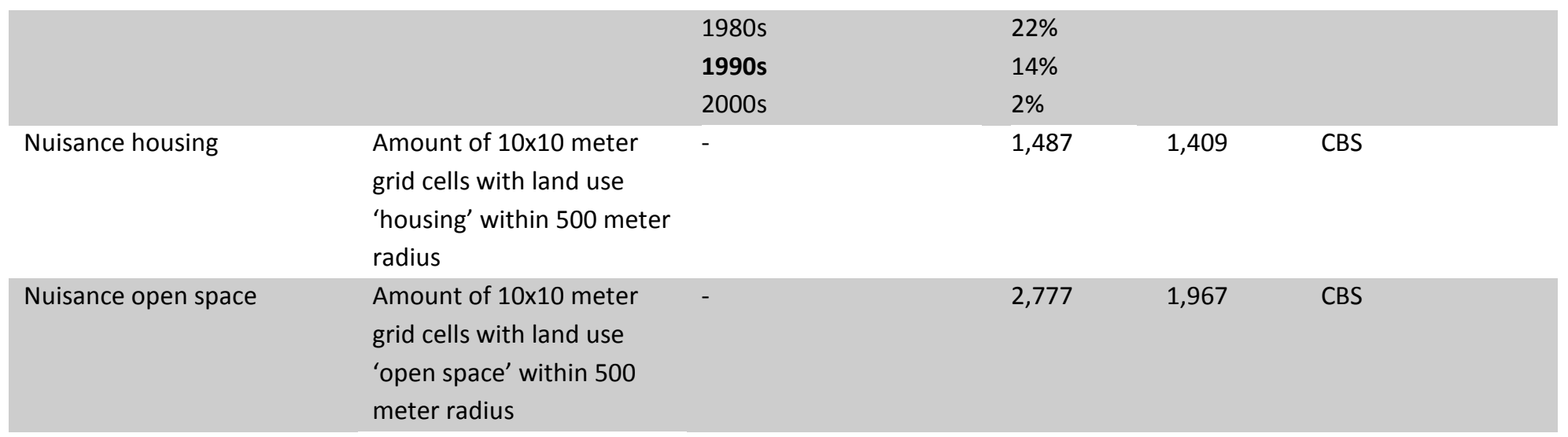

Regional economic characteristics

\begin{tabular}{|c|c|c|c|c|c|}
\hline Region & $\begin{array}{l}\text { Dummy variable for part } \\
\text { of the country in which } \\
\text { the industrial site is } \\
\text { located }\end{array}$ & $\begin{array}{l}\text { Centre (Randstad) } \\
\text { Intermediary zone } \\
\text { Periphery }\end{array}$ & $\begin{array}{l}30 \% \\
33 \% \\
37 \%\end{array}$ & - & PBL \\
\hline Density & $\begin{array}{l}\text { Number of addresses } \\
\text { within } 1 \text { kilometre radius }\end{array}$ & - & 664 & 709 & CBS \\
\hline Urbanisation rate & $\begin{array}{l}\text { Dummy variable for type } \\
\text { of settlement in which } \\
\text { industrial site is located }\end{array}$ & $\begin{array}{l}\text { Urban agglomeration } \\
\text { Suburban } \\
\text { Other }\end{array}$ & $\begin{array}{l}19 \% \\
17 \% \\
64 \%\end{array}$ & - & CBS \\
\hline
\end{tabular}

Economic trends

\subsection{Results of the analysis}

In this section, the results of our OLS model will be presented. The individual coefficients of the variables are listed in table 2 , along with the change in average property value in terms of percentages. Note that although year dummies were included in the model to account for economic trends, these were excluded from presentation to increase the readability of table 2 . The coefficients of the year dummies are discussed below.

Our model includes more than 27,000 cases for the period under research. The variables included in our model explain almost $37 \%$ of the average industrial property value on the industrial sites in our dataset. The overall explanatory value of the model is 0.3687 (adjusted R square) which is considered reasonable taking into consideration property specific characteristics are not included. A first closer look at our explanatory variables shows that almost all variables are significant at the $99 \%$ level. At this level there is sufficient evidence that the variables 'type of industrial site', 'sea port', 'water', 
'age', 'nuisance', 'region' and 'density' are significant in explaining the average property value of industrial sites. The variables 'accessibility' and 'located along motorway' are significant at the $95 \%$ level. In terms of the expected signs, only nuisance related to the presence of housing does not show the expected sign. The variables that do not significantly influence the average property value are 'urbanisation rate' and both categories of the centrality variable. Below, some of the most noticeable results are discussed in more detail.

The coefficients of the year dummies show the expected signs and patterns. Coefficients roughly show the expected signs, although compared to the reference year 1997 the first three years show a negative sign. The years in which periodic appraisals (2001, 2005 and 2007) were done can be recognised in shocks in the coefficients. Although the coefficients do not show the expected bust in the years 2003-2006 they appear to reflect inflation and corrections in value due to extensions.

If we take a closer look at the individual explanatory variables, the first notable result are the large differences in average value in terms of percentages between the categories of the variable 'type of industrial site'. Miscellaneous sites represent the highest property values, with a difference of $178 \%$ compared to mixed use sites. Sites that are dominated by consumer services and financial $\&$ business services show a difference of around $100 \%$. Also transport sites and sites dominated by industrial firms show higher average property values than mixed use sites, with more than $60 \%$ en $20 \%$ respectively, although a negative sign was expected for these two categories. The small number (only $2 \%$ ) of miscellaneous sites in the dataset might be an explanation for the relatively high value this category shows. The method of appraisal (see endnote iii) that is most commonly used for properties typically located at this type of industrial site might also have added to the high value for this particular category. Mixed-use industrial sites are plentiful in the Netherlands (this type makes up almost $30 \%$ of the sites in the dataset) and this type represents by far the lowest average property values. Industrial site specialisation, measured in terms of similar economic activities of firms located there, appears to be related to higher average property values. Higher average property values are frequently mentioned as a goal in redevelopment plans for declining urban areas. This means that for policy makers it can be interesting to regulate the types of firms to be located at a certain site when developing new sites or redeveloping existing ones.

The coefficients and corresponding changes in value of the accessibility variables are somewhat contrary to the conclusions by Ryan (2005). Accessibility by public transport and road both show the expected negative signs, indicating that access indeed significantly influences the average value of industrial sites, whereas Ryan's results suggested a negative relationship between accessibility via road 
and property value. Accessibility via water has a positive, although small, influence on average property value. This appears to indicate that firms value this extra form of accessibility.

Table 2: results of OLS regression

Dependent variable: natural logarithm of average industrial property value (per hectare) on industrial site

\begin{tabular}{|c|c|c|c|}
\hline & B & $\mathbf{t}$ & $\%$ value \\
\hline Constant & 9.297 & 99.380 & - \\
\hline \multicolumn{4}{|l|}{ Physical characteristics of industrial sites } \\
\hline \multicolumn{4}{|l|}{ Type of industrial site $(0 / 1)$} \\
\hline Mixed Use (ref) & - & - & \\
\hline Industry & $0.191 *$ & 5.970 & $21.0 \%$ \\
\hline Transport & $0.486 *$ & 10.520 & $62.6 \%$ \\
\hline Consumer services & $0.706 *$ & 11.010 & $103 \%$ \\
\hline Financial and business services & $0.674 *$ & 9.440 & $96.2 \%$ \\
\hline Miscellaneous & $1.025^{*}$ & 9.400 & $178 \%$ \\
\hline Sea port $(0 / 1)$ & $-0.351^{*}$ & -2.090 & $-29.7 \%$ \\
\hline \multicolumn{4}{|l|}{ Accessibility } \\
\hline By road (in minutes) & $-0.015^{* *}$ & -3.920 & $-1.5 \%$ \\
\hline By public transport (in km) & $-0.163^{*}$ & -2.790 & $-15.1 \%$ \\
\hline Water (ha within $500 \mathrm{~m}$ radius) & $0.025^{*}$ & 8.170 & $2.5 \%$ \\
\hline Located along motorway (0/1) & $0.115^{* *}$ & 2.370 & $12.2 \%$ \\
\hline \multicolumn{4}{|l|}{ Centrality } \\
\hline Distance from centre municipality (in km) & 0.098 & 1.050 & - \\
\hline Distance from nearest CBD (in km) & -0.001 & -0.710 & - \\
\hline \multicolumn{4}{|l|}{$\operatorname{Age}(0 / 1)$} \\
\hline 1950 s and before & $-0.678 *$ & -11.750 & $-49.3 \%$ \\
\hline 1960s & $-0.496 *$ & -8.780 & $-39.1 \%$ \\
\hline 1970s & $-0.430 *$ & -7.680 & $-34.9 \%$ \\
\hline $1980 s$ & $-0.216^{*}$ & -4.240 & $-19.4 \%$ \\
\hline 1990s (ref) & - & - & - \\
\hline $2000 s$ & $0.307^{*}$ & 3.360 & $35.9 \%$ \\
\hline \multicolumn{4}{|l|}{ Nuisance } \\
\hline Presence of housing (ha within $500 \mathrm{~m}$ radius) & $0.034^{*}$ & 19.290 & $3.5 \%$ \\
\hline $\begin{array}{l}\text { Presence of open space (ha within } 500 m \\
\text { radius) }\end{array}$ & $0.029 *$ & 22.270 & $2.9 \%$ \\
\hline Density (addresses per ha) & $0.016^{*}$ & 3.960 & $1.6 \%$ \\
\hline \multicolumn{4}{|l|}{ Regional economic characteristics } \\
\hline \multicolumn{4}{|l|}{$\operatorname{Region}(0 / 1)$} \\
\hline Centre (Randstad) & $0.261 *$ & 5.720 & $29.8 \%$ \\
\hline Intermediary zone (ref) & - & - & - \\
\hline Periphery & $-0.166^{*}$ & -4.000 & $-15.3 \%$ \\
\hline \multicolumn{4}{|l|}{ Urbanisation rate $(0 / 1)$} \\
\hline Urban agglomeration & 0.088 & 1.450 & - \\
\hline Suburban & -0.056 & -1.170 & - \\
\hline Other (ref) & - & - & - \\
\hline
\end{tabular}

$N=27,141$

Adj. $R^{2}=0.3687$

* significant at the $99 \%$ level $\quad * *$ significant at the $95 \%$ level

Standard errors are corrected to account for multiple observations of industrial sites over time 
As was expected, visibility from a motorway has a positive influence on the average value of an industrial site. When new industrial sites are planned, a location that is visible from a motorway can be favourable from the perspective of achieving the highest property values possible (for that reason, industrial firms usually pay higher prices for purchasing the land). A downside to this is that locations that are visible from the motorway are often greenfield locations. For the Netherlands, developing new industrial sites on greenfield locations adds to the loss of open space and is believed to have a harmful effect on the landscape (PBL, 2009b).

Both categories of centrality, distance from $\mathrm{CBD}$ and distance from centre of municipality, do not show significant results. A possible explanation is the overlap between these variables and density. Also, the linkages between location and accessibility, as were elaborated by Ryan (2005) is interesting to research more thoroughly.

The coefficients of the distinguished age classes show the expected signs and pattern. This is in line with hedonic pricing studies on individual property, where age is an important explanatory variable in many studies (see e.g. Buttimer et al. 1997; Jackson 2002; Dunse et al. 2004). From the results it can be concluded that the earlier the industrial site was developed, the lower the average property values are. The changes in value are not completely similar between decades, indicating that industrial sites from certain decades have lower average property values. An important explanation for lower average property values on older sites is the decrease in value because of decline ${ }^{\text {viii }}$. Industrial sites developed in the 1970s show relatively high property values compared to sites developed in the 1960 s with only $4 \%$ difference in value between these two decades. The difference between sites from the 1970s and 1980s however is almost $15 \%$. The same goes for industrial sites developed in the 1980 s with almost $20 \%$ difference in average property value compared to the reference category 1990s. This indicates that especially industrial sites from the 1970s and 1980s represent relatively low average property values. We do not have a proper explanation for this.

The signs of the variables that were included in the model to research the influence of nuisance are ambiguous. Both land use 'open space' and 'housing' have a positive effect on the dependent variable. However, the expectation was that the presence of housing and the nuisance for residents could turn into a negative location aspect for firms, reflected in lower average property values. More thorough research of the relationship between the average property value of an industrial site and surrounding land uses is needed to get more understanding of how these affect one another. 
The region in which an industrial site is situated has a significant effect on average property value. In line with the expectations values are highest in the Randstad, followed by the intermediary and peripheral zones respectively. Also density shows the expected sign; a higher number of addresses in the vicinity of the industrial site has a positive effect on the average property value of the site. Finally, for the urbanisation rate we did not find a significant relation with the dependent variable. The regression results for this variable indicate that average property values for industrial sites do not differ between urban agglomerations, suburban municipalities and other municipalities. The differences between regions appear not to be present at this spatial level, indicating that a location in an urban agglomeration vis-à-vis suburban and other municipalities does not have the same advantages as a location in the Randstad vis-à-vis the intermediary and peripheral zone.

Summarising the most important conclusions, we conclude that the highest average property values of industrial sites in the Netherlands can be found in the Randstad. Sites dominated by public services, hospitals and educational facilities (i.e. miscellaneous sites) show the highest average values, followed by sites that are characterised as financial \& business services sites and consumer services sites. Sites that are located along a motorway show on average $12 \%$ higher property values compared to sites that are not visible from the motorway. Industrial sites that were developed recently show the highest average property values and the coefficients indicate that the value of industrial sites decreases with age. The influence of other functions close to industrial sites is ambiguous, with both the presence of housing and open space showing a positive influence on the property value of an industrial site.

\section{Conclusions and further research}

\subsection{Conclusions}

Bryson (1997) argues that urban areas represent a certain value, which may change over time. The first goal of this paper was to analyse which variables influence this value of urban areas. To identify relevant variables, we used a method inspired by classic hedonic pricing studies. Moreover, we wanted to test whether this method that is conventionally used in studies of individual property, can also be applied in a meaningful way at the level of urban areas, notably industrial sites in the Netherlands.

In our study we considered the average property value of industrial sites to be an adequate representation of the value of this type of urban area. We used OLS regression to identify the relevancy of three categories of explanatory variables in the period 1997-2008: physical characteristics of the 
industrial site, regional economic characteristics and general economic trends. The selection of variables to be included in our model was based on the hedonic price literature of (industrial) property.

By and large, the results of the analysis appear to be in line with our hypotheses that were based on existing hedonic pricing literature. Both regional economic characteristics and physical characteristics of the urban area itself have the hypothesised significant influence on the value of the industrial sites under research. From this we conclude that the findings of this paper generate meaningful insight into the factors that influence the average property value of industrial sites. Our most notable findings in line with prior literature are with regard to the variables 'age', 'accessibility by road' and 'located along motorway'. Furthermore, the expected regional economic differences in average property value are reflected in the coefficients of the three distinguished regions of the Netherlands. Apart from the aforementioned confirmatory findings, we also obtained outcomes that differ from what we would have expected based on prior literature. The variables 'centrality' (both distance to CBD and centre municipality) and 'urbanisation rate' do not significantly influence property values. The results of both of these variables could be studied more extensively in relation to the accessibility of a location. Although not completely in line with our expectations, the results of the analysis for the variable 'type of industrial site' add new insights to the existing literature: the influence that the composition of firms located on an industrial site can have on the average property value has not been researched much in urban and property literature. 'Mixed-use' sites show the lowest average property values and at the same time make up a substantial part (30\%) of all industrial sites in the Netherlands. Specialisation in terms of the composition of firms located on an industrial site appears to have a positive influence on the average property value with specialised types of industrial sites, such as 'transport' and 'consumer services', showing significantly higher average property values.

These insights are useful for policy makers involved in urban regeneration and are applicable to urban areas that face decline. For now, we have chosen to use industrial sites in the Netherlands as a case study, since industrial sites in the Netherlands have received considerable attention because of rapid decline (van der Krabben and Buitelaar, 2011). Keeping property values at a high level is often an explicit goal of urban policies such as regeneration. The outcomes of this study can be useful for policy makers since it provides insight into the factors that affect the value of an urban area as a whole, contrary to a more narrow focus on factors that influence individual property value. This broader perspective can be of particular interest since it provides information on property value at a spatially relevant level, i.e. the level at which the outcomes of processes such as urban decline and gentrification 
are noticeable and could be influenced. For instance via the aforementioned specialisation of types of firms to be located at newly developed or regenerated industrial sites.

\subsection{Directions for further research}

This study shows important relations between locational characteristics and regional economic characteristics on the one hand, and average property value of designated urban areas on the other hand. For this study, industrial sites in the Netherlands have been used as a case study to test the proposed method and expected outcomes. Further research could concentrate on other urban areas that face processes such as decline and gentrification. More insight into what causes the differences in value between urban areas could result in more successful regeneration policies for example, or could even help to prevent urban areas from declining.

Future work will be aimed at the construction of an index, based on property values, that allows us to gain insight into the process of decline of urban areas. While constructing this indicator there are a few factors that will have to be taken into account. The idea that neighbourhoods go through life-cycles was introduced by Hoover and Vernon (1959) and recently applied theoretically to industrial sites in the Netherlands by Louw et al. (2004). If we assume that during the phases of the life cycle the average property value of an industrial site increases with growth, stabilises over time and eventually falls, this would mean that we must consider in more detail the changes in average property values. In this regard, it seems safe to assume that the average property value of an industrial site will be at its lowest point at the moment that the site has reached the end of its life cycle. However, one could argue that decline is most severe right after the phase of stabilisation, when the average property value (according to the life cycle) will fall sharply. These and other challenges will also be topic of future research. 
'Note that all of those studies were aimed at explaining the prices of individual properties, while the objective of the present study is to explain the average value (i.e. value per hectare) of industrial sites.

ii IBIS lists different measures for the surface of an industrial site. The one used here to calculate the average property value of a site is the surface that is actually in use by firms. This thus excludes public space, roads and land that was serviced, but was not yet sold to end users.

iii For taxation purposes, all property is appraised under the so called Real Property Act (Wet Onroerende Zaken or WOZ) which was first introduced in 1997. Since 2007 property is appraised annually, from 1997 till 2004 this was done once every four years and between 2004 and 2006 the appraisal was done bi-annually. During these periods, the appraised value was only corrected for inflation and not for redevelopment or extensions. For the majority of industrial property the method used for appraisal is based on known transactions of similar properties within the municipality. Some types of industrial property with few transactions (for example energy plants, hospitals, waste processing plants, schools etc.) are appraised by calculating the replacement costs of the property. Although this method will result in property values which are not affected by obsolescence (nor deterioration) this will not influence our results since they only make up a small number in our database. There are two reasons for this. First, outliers were defined and a considerable number of these types of properties have (very) high replacement costs. Second additional research shows that only a very small percentage of the properties are schools, hospitals and the like. Results of this analysis are available upon request.

iv Although most types are straightforward, the categories 'mixed-use' and 'miscellaneous' need some extra explanation. 'Mixed-use' refers to a mix of different types of businesses, rather than a mix of different land uses such as residential, shopping, etc. 'Miscellaneous' refers to a final category of industrial sites that, based on the types of firms located there, mostly houses schools, hospitals and government services.

'This is confirmed by a weak correlation (-.36) between the explanatory variables 'accessibility by road' and 'located along motorway'

vi The travelling time is calculated as the travelling time from every individual property divided by the total amount of properties. This is called the average travelling time (of the industrial site). The same goes for all variables that are defined in terms of distance, unless mentioned otherwise.

${ }^{\text {vii }}$ Note that on some sites developments may continue after this date. Also, redevelopment may have taken place that have made new developments possible. Still, the decade in which the first development took place is a good indicator for the age of the industrial site as a whole.

viii Although the relation between decline and decrease in value can be debated extensively, for here we assume that age in general is the most important driver of decline. 


\section{References}

Ambrose, W. (1990). An analysis of the factors affecting light industrial property valuation. The journal of real estate research 5(3): 355-69.

Black, R., M. Wolverton, J. Warden en R. Pittman (1997). Manufacturing versus Distribution: Implicit Pricing of Real Property Characteristics by Submarket. Journal of Real Estate Finance and Economics 15(3): 271-285.

Bryson, J. M. (1997) Obsolescence and the Process of Creative Reconstruction. Urban Studies, 24, 1439-1458.

Buttimer, R., R. Rutherford en R. Witten (1997). Industrial Warehouse Rent Determinants In the Dallas/Fort Worth Area. Journal of Real Estate Research 13(1): 47-55.

CBS Netherlands Statistics (2005). Grootstedelijke agglomeraties en stadsgewesten afgebakend. Voorburg/Heerlen, Centraal Bureau voor de Statistiek.

Cheshire, P. and Hay, G. (1998) Urban Problems in Western Europe: an economic analysis, London, Unwin Hyman.

CPB Netherlands Bureau for Economic Policy Analysis (2001). Veroudering van bedrijventerreinen: een structuur voor herstructurering. Den Haag, Centraal Planbureau.

de Vor, F. en H. de Groot (2011). The Impact of Industrial Sites on Residential Property Values: A Hedonic Pricing Analysis from the Netherlands. Regional Studies 45(5): 609-623.

Derbes, M. J. (2002). Non-Comparable Industrial Sales. The Appraisal Journal 70(1): 39-45.

Dunse, N. en C. Jones (1998). A Hedonic Price Model of Office Rents. Journal of Property Valuation \& Investment 16(3): 297-312.

Dunse, N. en C. Jones (2005). Rental Depreciation, Obsolescence and Location: the Case of Industrial Properties. Journal of Property Research 22(2-3): 205-223.

Dunse, N., C. Jones, J. Brown en W. D. Fraser (2004). The spatial pattern of industrial rents and the role of distance. Journal of Property Investment \& Finance 23(4): 329-341.

Fehribach, F., Rutherford, R. \& Eakin, M. (1993) An Analysis of the Determinants of Industrial Property Valuation. The journal of real estate research, 365-371.

Glascock, J. L., Jahanian, S. \& Sirmans, C. F. (1990) An analysis of office market rents: some empirical evidence. American Real Estate and Urban Economics Association Journal, 18, 105-119.

Gunterman, K. L. (1995) Sanitary Landfills, Stigma and Industrial Land Values. The journal of real estate research, 10, 531-542.

Hoag, J. (1980). Towards Indices of Real Estate Value and Return. The Journal of Finance 35(2): $569-580$.

Hoover, E. M. \& Vernon, R. (1959) Anatomy of a metropolis: The changing distribution of people and jobs within the New York metropolitan region, Cambridge, Harvard University Press.

IBIS (2012). Toelichting begrippen IBIS. Den Haag, Ministerie van Infrastructuur en Milieu.

Jackson, T. (2002). Environmental Contamination and Industrial Real Estate Prices. Journal of Real Estate Research 13(1/2): 179-99.

Lockwood, L. en R. Rutherford (1996). Determinants of Industrial Property Value. Real Estate Economics 24(2): 257-272. 
Louw, E., Needham, B., Olden, H. \& Pen, C. J. (2004) Planning van bedrijventerreinen, Den Haag, Sdu Uitgevers.

Malpezzi, S. (2003). Hedonic Pricing Models: a Selective and Applied Review. Housing Economics and Public Policy: Essays in Honor of Duncan Maclennan. T. O. Sullivan and K. Gibbs. Oxford, Blackwell.

Needham, B. (1992) A Theory of Land Prices when Land is Supplied Publicly: The Case of the Netherlands. Urban Studies, 29, 669-686.

Pen, C. J. (2002) Wat beweegt bedrijven. Besluitvormingsprocessen bij verplaatste bedrijven, Utrecht/ Groningen, Koninklijk Nederlands Aardrijkskundig Genootschap/ Faculteit der Ruimtelijke Wetenschappen Rijksuniversiteit Groningen.

Páez, A., Long, F. \& Farber, S. (2007) Moving Window Approaches for Hedonic Price Estimation: An Empirical Comparison of Modelling Techniques. Urban Studies, 45, 8, 1565-1581.

PBL Netherlands Environmental Assessment Agency (2008) Werkgelegenheidsgroei op bedrijventerreinen, Den Haag, Planbureau voor de Leefomgeving.

PBL Netherlands Environmental Assessment Agency (2009b) De toekomst van bedrijventerreinen: van uitbreiding naar herstructurering, Den Haag, Planbureau voor de Leefomgeving

PBL Netherlands Environmental Assessment Agency (2009a). De waarde van de kantooromgeving. Den Haag, Planbureau voor de Leefomgeving.

Ploegmakers, H. and P. Beckers (2012) Evaluating Regeneration Policies for Rundown Industrial Sites in the Netherlands. Working Paper 8. The Hague, PBL Netherlands Environmental Assessment Agency. Retrieved from: http://www.pbl.nl/en/publications/2012/evaluating-regeneration-policies-for-rundownindustrial-sites-in-the-netherlands, 13-12-2012.

Reed, R. (2012). The increasing importance of social sustainability - the contribution of social area analysis in housing market analysis. European Real Estate Society 19th Annual Conference. Edinburgh.

Rosen, S. (1974) Hedonic Prices and Implicit Markets: Product Differentitation in Pure Competition. The Journal of Political Economy, 82, 34-56.

Ryan, S. (2005). The Value of Acces to Higways and Light Rail Transit: Evidence for Industrial and Office Firms. Urban Studies 42(4): 751-764.

Sivitanidou, R. en P. Sivitanides (1995). Industrial Rent Differentials: The Case of Los Angeles. Environment and Planning A 27: 1133-1146.

Stec Groep (2005) Bedrijfsruimtegebruikers in Beeld: Resultaten Database Bedrijfsruimtegebruikers Nederland 2005:. Nijmegen, Stec Groep.

Taskforce Herontwikkeling Bedrijventerreinen (2008). Kansen voor kwaliteit: een ontwikkelingsstrategie voor bedrijventerreinen. Den Haag, Ministerie van VROM Ministerie van EZ.

Van der Krabben, E. and E. Buitelaar (2011). Industrial land and property markets: market processes, market institutions and market outcomes. The Dutch Case. European Planning Studies, 19(12), 2127-2146.

Van Oort, F. (2004). Urban Growth and Innovation. Spatially Bounded Externalities in the Netherlands. Aldershot, Ashgate. 
Vastgoedmonitor. (2012). Gemiddelde verkoopprijs bedrijfsruimte 2000-2007 Nederland. Retrieved 23-03-2012, from http://www.vastgoedmonitor.nl.

Waarderingskamer (2011) WOZ-Uitvoering: (modelmatige) waardebepaling niet-woningen.

Walks, R. A. \& Maaranen, R. (2008) Gentrification, Social Mix and Social Polarization: Testing the Linkages In Large Canadian Cities. Urban Geography, 29, 293 - 326.

Wheaton, W. \& Torto, R. (1994) Office rent indices and their behaviour over time. Journal of Urban Economics, 35, 121-139. 